\title{
Factors Associated with Overweight and Obesity in an Urban Area of South East Nigeria
}

\author{
Uchenna Nkemdilim Ijoma ${ }^{1}$, Peter Chime ${ }^{2}$, Chinwe Onyekonwu ${ }^{1}$, \\ Birinus Adikaibe Ezeala-Adikaibe ${ }^{1,2 *}$, Casmir Orjioke ${ }^{2}$, Obumneme Benneth Anyim², \\ Obinna Donatus Onodugo', Eddy Aneke², Chidimma Brenda Nwatu1, Ekenechukwu Young1, \\ Nkeiruka Mbadiwe', Oluchi Stella Ekenze', Julius Uwabunkeonye Okoye', Michael Abonyi², \\ Ifeoma Isabella Ulasi' ${ }^{1}$, Anthony Mbah'1, Pauline Nkiruka Onodugo' ${ }^{1}$
}

\author{
${ }^{1}$ Department of Medicine, University of Nigeria Teaching Hospital, Enugu, Nigeria \\ ${ }^{2}$ Department of Medicine, Enugu State University Teaching Hospital, Enugu, Nigeria \\ Email: ^birinusadikaibe@gmail.com
}

\begin{abstract}
How to cite this paper: Ijoma, U.N., Chime, P., Onyekonwu, C., Ezeala-Adikaibe, B.A., Orjioke, C., Anyim, O.B., Onodugo, O.D., Aneke, E., Nwatu, C.B., Young, E., Mbadiwe, N., Ekenze, O.S., Okoye, J.U., Abonyi, M., Ulasi, I.I., Mbah, A. and Onodugo, P.N. (2019) Factors Associated with Overweight and Obesity in an Urban Area of South East Nigeria. Food and Nutrition Sciences, 10, 735-749.

https://doi.org/10.4236/fns.2019.107054
\end{abstract}

Received: May 21, 2019

Accepted: July 9, 2019

Published: July 12, 2019

Copyright $\odot 2019$ by author(s) and Scientific Research Publishing Inc. This work is licensed under the Creative Commons Attribution International License (CC BY 4.0). http://creativecommons.org/licenses/by/4.0/ Open Access

\begin{abstract}
Background: Overweight and obesity present a growing health problem among Africans from all socioeconomic status. In Sub Saharan African, obesity is not only a consequence of overnutrition but possibly from excessive consumption of unbalanced diet dominated by carbohydrates and saturated fats. Characteristics of the distribution of obesity/overweight in Nigeria include its high prevalence along with socioeconomic class and in mid-life. Methods: Using the WHO STEP-wise approach to surveillance of noncommunicable diseases, we conducted a cross-sectional descriptive study of the adult population living in two urban slums in Enugu. The study was carried out in 2013. Statistical analysis was done using SPSS version. Results: A total of 605 (414 women (68.4\%) and 191 (31.6\%) men were recruited and analysed. The mean body mass index was $25.8 \mathrm{~kg} / \mathrm{m}^{2}$ higher in females $(26.7$ $\left.\mathrm{kg} / \mathrm{m}^{2}\right)$ than males $\left(24 \mathrm{~kg} / \mathrm{m}^{2}\right) \mathrm{p}<0.01$. The prevalence of overweight and obesity is $29.4 \%(178 / 605)$ and $19.5 \%(118 / 605)$ respectively. There also a modest prevalence of underweight $4 \%(24 / 605)$ among the population. All classes of obesity were significantly more prevalent in females. Significant positive correlates of BMI were: female sex $(r=0.21, p<0.001)$, systolic blood pressure $(0.25, \mathrm{p}<0.001), \mathrm{DBP}(0.27, \mathrm{p}<0.001)$, fasting blood glucose $(0.19, \mathrm{p}<$ $0,001)$ and positive history of hypertension $(0.23, \mathrm{P}<0.001)$. Negative correlates were physical activity and use of tobacco $(0.2 \quad(<0.001)$ and -0.16 $(<0.001)$ respectively). Conclusion: The prevalence of obesity is relatively high in two urban slums in Enugu and co-exists with a modest rate of underweight. Public health and community-based approaches should be used to tackle these two-opposing social/health problems.
\end{abstract}




\section{Keywords}

Obesity, Overweight, Hypertension, Diabetes, Nigeria

\section{Introduction}

Overweight and obesity present a growing health problem among Africans from all socioeconomic status [1] [2] [3] [4] [5]. In Sub Saharan African (SSA), obesity is not only a consequence of overnutrition but possibly from excessive consumption of unbalanced diet dominated by carbohydrates and saturated fats [4] [5]. Poor nutrition coupled with low levels of physical activity associated with urbanization as well as other factors has resulted in high rates of metabolic syndrome and other non-communicable diseases in the sub-continent [6] [7]. Obesity is a risk factor for premature death for individuals younger than 65 years old, it is a risk factor of many cardiovascular and non-cardiovascular disorders including several types of cancers, arthritis, gall bladder stone and amenorrhea [5] [8].

Worldwide, an estimated 2.8 million people die each year from complications related to obesity [9]. The prevalence of obesity in West Africa was estimated at $10.0 \%$ [10] but vary widely within the region [9] [10] [11] [12]. The prevalence of obesity in SSA ranged from $3.5 \%$ in Eritrea to about $64 \%$ in Seychelles. Women, in general, have higher prevalence of overweight and obesity than men in all SSA countries. The highest prevalence of overweight is in Seychelles (73.8\%) while the lowest in Ethiopia (3.7\%) [9].

In Nigeria, the prevalence of overweight individuals ranged from $20.3 \%$ $35.1 \%$, while the prevalence of obesity ranged from $4.6 \%-22.2 \%$ [1] [2] [3] [13]-[22]. The prevalence of obesity and overweight varies between geographical regions in Nigeria. Higher prevalences have been recorded in southern parts of the country with female preponderance [1] [2] [3] [13] [14] [15] [17] [18] [19] [20]. Among the Kalabaris [1] (south-south Nigeria) where fattening rituals may be performed for women, that prevalence of obesity was estimated at $47.3 \%$. Other characteristics of the distribution of obesity/overweight in Nigeria include its high prevalence along with socioeconomic class and in mid-life [13]-[19] with some studies reporting that more than $55 \%$ were either overweight or obese [1] [13]. The peak prevalence of obesity in most studies from Nigeria is midlife [1] [2] [3] [15] [20], while the lowest prevalence of obesity is observed below 20 years [15] [20].

Reports from other SSA countries have reported high prevalence of obesity.

The prevalence of obesity reported in Ouagadougou, Burkina Faso in 2014, gave a $30.5 \%, 22 \%$ prevalence of overweight and obesity respectively [23]. Systemic reviews and other studies on the subject suggest high and wide ranges in the prevalence of overweight and obesity [5] [6] [9] [12] [24] [25]. It is important however to note that most SSA studies were conducted in large urban centers in these countries and may not necessarily be representative of the whole 
nation. Generally, though the prevalence of overweight and obesity is lower in rural SSA [5] [6]. Quantifying the prevalence of obesity is important to draw health policy makers attention to address this problem.

The aim of this study was to describe the prevalence of overweight, obesity in an urban settlement in Enugu, South East Nigeria.

\section{Methods}

\subsection{Setting}

Using a purposive sampling method, we selected 2 urban settlements (Agu-Abor and Ugbodogwu) in Enugu, the capital of Enugu State, Southeast Nigeria. The two settlements have an estimated adult population of 7000 - 9000 individuals (based on church and local records). The total area occupied by both settlements is approximately $2.5-5 \mathrm{~km}^{2}$ and are located about $1-2.5 \mathrm{~km}$ from the nearest state-owned teaching hospital. The two settlements were selected purposively because of their relatively isolated location. The inhabitants of Agu-abor were surveyed over a 4-week period (August 12 -September 9, 2013), while Ugbodogwu inhabitants were surveyed between November 25-December 21, 2013. This study was approved by the ethics committee of the University of Nigeria Teaching Hospital Ituku/Ozalla, P M B 01129 Enugu. No NHREC/05/01/2008B-FWA00002458-1RB00002323. Date of approval $28^{\text {th }}$ July 2013. Informed consent was obtained from all participants.

\subsection{Study Design}

A cross-sectional descriptive study was done to survey the adult population living in both localities. The study was preceded by sensitization meetings in the community which included both religious and elected leaders. Community-wide awareness announcements were carried out in churches and other public places. Following community entry, all participants who came out for the survey were interviewed by teams of research assistants. Using the WHO STEPS instrument [26], data on selected socio-demographic characteristics and lifestyle behaviors including, physical activity was collected. Inclusion criteria was all consecutive consenting adults 20 years and above, while the exclusion criteria were a refusal to participate. Pregnant women, patients on steroids and individuals who could not be weighed or have their heights measured were interviewed but their data were not included in the final analysis. Clinical assessment of the participants was carried out in a field. Data on weight, height, blood pressure, fasting blood glucose, as well as past medical history, were collected at this phase of the study. Biochemical measurements (excluding fasting blood glucose) were not done.

Body mass index (BMI) was calculated as weight $(\mathrm{Kg})$ divided by squared height $\left(\mathrm{m}^{2}\right)$ and categorized as underweight $<18.5 \mathrm{~kg} / \mathrm{m}^{2}$, normal weight 18.5 $24.9 \mathrm{~kg} / \mathrm{m}^{2}$, Overweight $25-29.9 \mathrm{~kg} / \mathrm{m}^{2}$, Obese $\geq 30 \mathrm{~kg} / \mathrm{m}^{2}$. Obesity was defined as BMI $\geq 30 \mathrm{mg} / \mathrm{m}^{2}$ based on WHO criteria [27]. Blood pressure was measured after 5 - 10 minutes rest in a sitting position and was measured thrice by means 
of mercury sphygmomanometer according to the guidelines of the European Society of Hypertension [28].

Weight was measured using a standard bathroom scale in kilograms (nearest $0.5 \mathrm{~kg}$ ). Scales were calibrated and recalibrated on daily basis by re-adjusting their pointers to zero. At the beginning of the study, scales were compared with standard scales used in the hospital. Bathroom scales were used because of cost and availability.

Height was measured in centimetres using a straight centimetre ruler with the patient standing erect on a flat surface.

Fasting blood glucose (FBG) was measured using a glucometer (Fine test premium, Infobia co Ltd, Dongan-gu. South Korea) after an overnight fast. The fine test control solution was used to check and test strips to make sure they are properly working. Classification of diabetes and prediabetes was based on the WHO criteria [29].

Diabetes was defined as the previous history of diabetes and/or use of hypoglycemic agents and FBG within the diabetic range on two occasions during the survey period [29]. Individuals with systolic blood pressure (SBP) of $\geq 140$ $\mathrm{mmHg}$ and/or diastolic blood pressure (DBP) of $\geq 90 \mathrm{mmHg}$, past medical history of hypertension and/or use of anti-hypertensive drugs were considered as having hypertension. Stroke was defined as a clinical syndrome of rapidly progressive symptoms and signs of focal or global neurological deficit lasting more than one hour of which there is no apparent cause other than the vascular origin, and/or past medical history of stroke diagnosed by qualified personnel (doctors). Current tobacco use was defined as the use of any form of tobacco in the past 4 weeks. Estimated alcohol use and quantity were defined as (mean quantity) the consumption of any alcoholic beverage in a week. Artisans were defined as skilled manual laborers. Physical activity was graded based on the 2008 Physical Activity Guidelines for Americans [30]. Office workers getting little or no exercise were classified as having sedentary life style or low physical activity. Construction workers, artisans/ craftsmen or persons running $1 \mathrm{~h}$ daily were categorized as having moderate physical activity. Agricultural workers or person swimming $2 \mathrm{~h}$ a day or all cases where total activity exceeds that of those with moderate activity such as artisans who are involved in the lumber industry were grouped as having vigorous physical activity. Levels of physical activity were estimated based on the type of occupation, time spent at work and recreational activities (total weekly amounts of physical activity).

Level of education was the individual's highest educational (formal) attainment based on the Nigerian school system.

Sample size was calculated using the Taro Yamane formula [31], N = N/1 + $\mathrm{N}(\mathrm{e})^{2}$. Where: $\mathrm{n}=$ required sample size, $\mathrm{e}^{2}=$ error limit and $\mathrm{N}=$ estimated adult population in both settlements.

$\mathrm{N}$ = estimated population of the community (9000), $\mathrm{e}=0.05$.

$\mathrm{N}=9000 / 9000 * 0.0025=9000 / 22.5=400$. With an expected $10 \%$ attrition rate, a minimum of 440 individuals will be screened. 


\subsection{Statistical Methods}

For database management and statistical analyses, we used the SPSS version 20 (IBM Corporation, New York, USA). Data were presented in tables. For continuous variables, mean values and $95 \%$ confidence intervals were calculated. Prevalence of diabetes and prediabetes were expressed as percentages and confidence interval calculated. Mean values were compared using the independent t-test and the Mann-Whitney $U$ test where applicable. In all, p values of $<0.05$ were regarded as statistically significant. The confidence level was kept at $95 \%$.

\section{Results}

Data from 605 (74.6\%) participants out of the 811 who were initially screened at home (414 women $(68.4 \%)$ and $191(31.6 \%)$ men $\mathrm{p}<0.01)$ based on the study protocol were analysed. About 72.6\% (433/605) came from Ugbodogwu and $28.4 \%(172 / 605)$ came from Aguabor. The male to female ratio of those screened was $0.5: 1$. The distribution of the participants showed that 444 (54.7\%) came from Ugbodogwu while 367 (45.3\%) were from Aguabor. The age distribution of the participants is shown in Table 1 . They were aged 20 to 90 years, with a mean age of 44.5 (43.3 - 45.8) years (Males: 51.1 and females: 41.5 years, $\mathrm{p}<0.01)$. Females were shorter but weighed the same as males. most of the subjects were artisans or managers of small-scale businesses. Majority stopped at secondary school level in their education (51.6\%). Male participants drank alcohol more than the female participants (males 160 (83.8\%), females $306(73.9 \%), \mathrm{P}<0.01$ ) and used tobacco (males 73 (38.2\%), females 61 (14.7\%), $\mathrm{P}<0.01$ ) (Table 1).

The distribution of fasting blood glucose and mean blood pressure measurements are also shown in Table 1. Mean fasting glucose level was similar in males and females. $\mathrm{P}=0.98$. The mean blood pressure of the participants was 133.7 mmHg (95\% CI, 131.7 - 135.9) systolic and $83.4 \mathrm{mmHg}$ (95\% CI, 82.4 - 84.7) diastolic. Systolic blood pressure was significantly higher in males than in females. $\mathrm{P}$ $=0.01$. Past medical history of hypertension, previous diabetes and stroke was documented in $23 \%, 5.3 \%$ and $2.8 \%$ of the population sample respectively.

\section{Overweight and Obesity}

The distribution of BMI in the study population is shown in Table 2. The mean body mass index (BMI) was $25.8 \mathrm{~kg} / \mathrm{m}^{2}$ higher in females $\left(26.7 \mathrm{~kg} / \mathrm{m}^{2}\right)$ than males $\left(24 \mathrm{~kg} / \mathrm{m}^{2}\right) \mathrm{p}<0.01$. A total of $178(29.4 \%)$ were overweight, there was no gender disparity. $\mathrm{P}=0.67$. Only $24(4 \%)$ of the population studied were underweight. Greater proportion of males had normal BMI $(\mathrm{p}<0.001)$ while greater proportion of females were obese $(p<0.001)$. Distribution of mean values of Systolic blood pressure (SBP), diastolic blood pressure (DBP) and fasting blood glucose by Body mass index is shown in Figure 1.

All classes of obesity were significantly more prevalent in females (Table 3 ). Whereas none of the males had grade III obesity, IT was seen in $3.4 \%$ of the females. The age distribution of obesity showed that obesity peaked from 45 - 54 
Table 1. Characteristics of participants.

\begin{tabular}{|c|c|c|c|c|}
\hline Characteristic & Women & Men & Total & P-value ${ }^{\beta}$ \\
\hline \multicolumn{5}{|l|}{ Anthropometrics } \\
\hline Women, $\mathrm{n}$ & $414(68.4)$ & $191(31.6)$ & $605(100)$ & $<0.001$ \\
\hline Age, years(mean 95\%CI) & $41.5(40.2-42.9)$ & $51.1(48.7-53.5)$ & $44.5(43.3-45.8)$ & $<0.001$ \\
\hline Height, cm (mean 95\%CI) & $158.2(157.5-159)$ & $165.3(164.2-166.5)$ & $160.5(159.8-161.1)$ & $<0.001$ \\
\hline Weight, kg (mean 95\%CI) & $66.9(65.2-68.6)$ & $65.6(63.8-67.4)$ & $66.5(65.2-67.8)$ & 0.38 \\
\hline \multicolumn{5}{|l|}{ Age group } \\
\hline$<35$ & $151(36.5)$ & $42(21.8)$ & $193(31.9)$ & \multirow{5}{*}{$<0.001$} \\
\hline $35-44$ & $88(21.3)$ & $15(7.9)$ & $103(17)$ & \\
\hline $45-54$ & $91(22)$ & $49(25.7)$ & $140(23.1)$ & \\
\hline $55-64$ & $58(14)$ & $34(17.8)$ & $92(15.2)$ & \\
\hline$\geq 65$ & $26(6.3)$ & $51(26.7)$ & $77(12.7)$ & \\
\hline \multicolumn{5}{|l|}{ Occupation } \\
\hline Students & $46(11.1)$ & $21(11)$ & $67(11.1)$ & \\
\hline Artisans/business & $225(54.3)$ & $88(46.1)$ & $313(51.7)$ & \\
\hline Civil servants & $41(9.9)$ & $31(16.2)$ & $72(11.9)$ & \\
\hline Retired/unemployed/others & $57(13.8)$ & $40(20.9)$ & $97(16)$ & \\
\hline Farmers & $45(10.9)$ & $11(5.8)$ & $56(9.3)$ & 0.01 \\
\hline \multicolumn{5}{|l|}{ Level of Education } \\
\hline None /Primary & $196(47.3)$ & $97(50.8)$ & $293(48.4)$ & \\
\hline Secondary and above & $218(52.7)$ & $94(49.2)$ & $312(51.6)$ & 0.43 \\
\hline \multicolumn{5}{|l|}{ Peripheral hemodynamics* } \\
\hline Systolic pressure, mm Hg (mean 95\% CI) & $132(129.3-134.6)$ & $137.8(134.3-141.3)$ & $133.7(131.7-135.9)$ & 0.01 \\
\hline Diastolic pressure, $\mathrm{mm} \mathrm{Hg}$ (mean 95\% CI) & $83.1(81.5-84.7)$ & $84.0(81.7-86.2)$ & $83.4(82.4-84.7)$ & 0.51 \\
\hline Measurements on blood (mean 95\% CI) & - & - & - & - \\
\hline Glucose, mg/dL (mean 95\% CI) & $96.5(93.7-99.3)$ & $96.6(92.2-101)$ & $96.5(94.2-98.9)$ & 0.98 \\
\hline Lifestyle & - & - & - & - \\
\hline Current tobacco use, n (\%) & $61(14.7)$ & $73(38.2)$ & $134(22.1)$ & $<0.001$ \\
\hline Current alcohol use, n (\%) & $306(73.9)$ & $160(83.8)$ & $466(77)$ & 0.01 \\
\hline Quantity (mean units/week) & $0.04(0.034-0.041)$ & $0.06(0.05-0.07)$ & $0.73(0.66-0.81)$ & $<0.001$ \\
\hline Medical History of & - & - & - & - \\
\hline Hypertension & $93(22.5)$ & $46(24.1)$ & $139(23)$ & 0.66 \\
\hline Diabetes & $15(3.6)$ & $17(8.9)$ & $32(5.3)$ & 0.01 \\
\hline Stroke & $10(2.4)$ & $7(3.7)$ & $17(2.8)$ & 0.39 \\
\hline \multicolumn{5}{|l|}{ Physical Activity } \\
\hline Vigorous activity & $82(19.8)$ & $69(36.1)$ & $151(25)$ & \\
\hline Moderate activity & $239(57.7)$ & $53(27.7)$ & $292(48.3)$ & \\
\hline Low Activity (sedentary) & $93(22.5)$ & $69(36.1)$ & $162(26.8)$ & $<0.001$ \\
\hline
\end{tabular}

${ }^{\beta} \mathrm{P}$-values are for the sex differences. ${ }^{\star}$ Peripheral systolic and diastolic blood pressure were the average of 3 consecutive measurements. 
Table 2. Sex distribution of Body Mass.

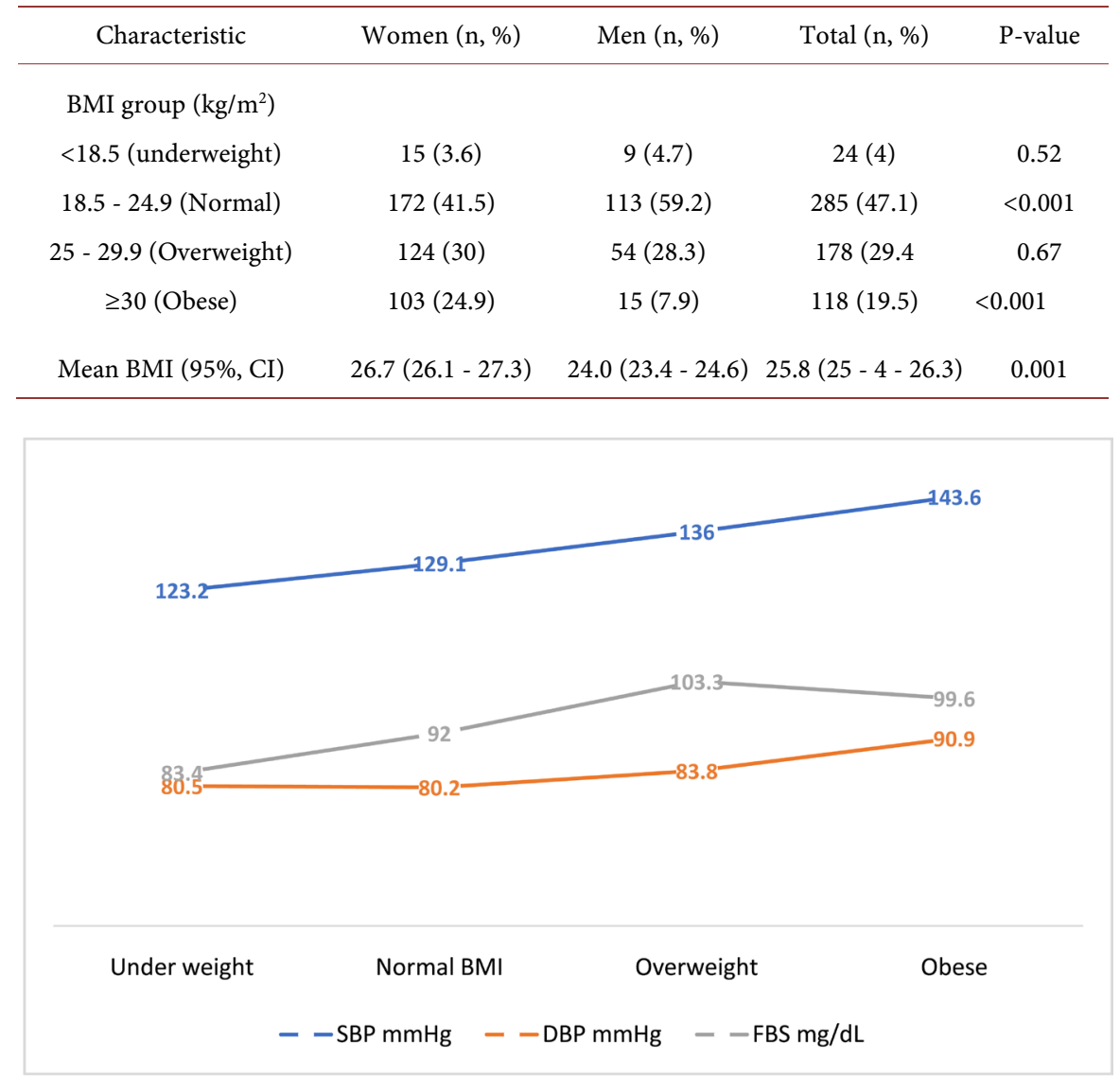

Figure 1. Distribution of mean values of Systolic blood pressure (SBP), Diastolic blood pressure (DBP) and Fasting blood glucose (FBS) by Body mass index.

Table 3. Prevalence of obesity in the community.

\begin{tabular}{ccccc}
\hline Characteristic & $\begin{array}{c}\text { Total } \\
\mathrm{N}(\%)\end{array}$ & $\begin{array}{c}\text { Males } \\
\mathrm{N}(\%)\end{array}$ & $\begin{array}{c}\text { Females } \\
\mathrm{N}(\%)\end{array}$ & p-value \\
\hline Overweight & $178(29.4)$ & $54(28.3)$ & $124(30)$ & 0.67 \\
Obesity & $118(19.5)$ & $15(7.9)$ & $103(24.9)$ & $<0.001$ \\
Class I & $76(12.6)$ & $12(6.3)$ & $64(15.5)$ & $0.01^{\star *}$ \\
Class II & $26(4.3)$ & $3(1.6)$ & $23(5.6)$ & $0.02^{\star *}$ \\
Class III & $14(2.3)$ & - & $14(3.4)$ & $0.01^{\star *}$ \\
Prevalence of obesity in & & & & \\
different groups & & & & \\
Age group & & & & \\
& & & & \\
445 & $54(18.2)$ & $2(3.5)$ & $28(30.8)$ & 0.02 \\
$45-54$ & $34(24.3)$ & $6(12.2)$ & $7(2.9)$ & $0.01^{\star *}$ \\
55 - 64 & $17(18.5)$ & $6(11.8)$ & $7(26.9)$ & 0.09 \\
$\geq 65$ & $13(16.9)$ & &
\end{tabular}

${ }^{*}$ Fisher's exact test. 
Table 4. Correlates and predictors of obesity in the study population.

\begin{tabular}{cccc}
\hline & $\mathrm{R}(\mathrm{p}$-value $)$ & Obesity $\left(\mathrm{R}^{2}=0.125\right) \mathrm{B}(\mathrm{SE})$ & $\mathrm{p}$-value \\
\hline Age & $0.06(0.14)$ & - & \\
Gender (0 Female, 1 Male) & $-0.2(<0.001)$ & $-0.18(0.03)$ & $<0.001$ \\
$\begin{array}{c}\text { Level of education (1 Primary, } \\
\text { 2 Secondary, 3 Tertiary) }\end{array}$ & $-0.02(0.63)$ & - & \\
Systolic blood pressure & $0.17(<0.001)$ & $0.0(0.001)$ & 0.82 \\
Diastolic blood pressure & $0.24(<0.001)$ & $0.01(0.21)$ & $<0.001$ \\
Fasting blood glucose & $0.09(0.03)$ & $0.0(0.0)$ & - \\
Use of tobacco (1 Yes, 0 No) & $-0.07(0.07)$ & - & \\
Use of alcohol (1 Yes, 0 No) & $0.02(0.69)$ & $-0.9(0.02)$ & $<0.001$ \\
$\begin{array}{c}\text { Physical activity (1 sedentary, } \\
\text { 2 moderate, 3 vigorous) }\end{array}$ & $-0.16(<0.001)$ & & \\
\hline
\end{tabular}

years. This pattern was similar in males and females. As expected obesity was more prevalent in people with sedentary lifestyles $25.3 \%$ (Table 3 ).

Table 4 shows the results of Pearson correlation statistics of different variables with BMI. Significant positive correlates were: sex $(-0.21, \mathrm{p}<0.001)$, SBP $(0.25$, $\mathrm{p}<0.001)$, DBP $(0.27, \mathrm{p}<0.001)$, fasting blood glucose $(0.19, \mathrm{p}<0,001)$ and positive history of hypertension $(0.23, \mathrm{P}<0.001)$. Negative correlates were physical activity and use of tobacco. Multivariate logistic regression results (enter method). Females sex, diastolic blood pressure, history of hypertension and level of physical activity were significant predictors of BMI.

\section{Discussion}

Overweight/obesity is an important aspect of the multidimensional health challenges facing the SSA. Major risk factors for the disease entities such as hypertension, diabetes and cerebrovascular/cardiovascular disease are largely preventable by basic and simple measures such as lifestyle changes. This is especially true for obesity. Current estimates on the prevalence of overweight and obesity in SSA vary widely because of several overlapping factors: cultural, socioeconomic status, levels of physical activity as well as genetic [5] [6]. In a study from Sokoto in North West Nigeria, more than $12.5 \%$ and $9.7 \%$ of the university staff interviewed believed that obesity is good and God-given respectively [32]. Among the Kalabaris in South-south Nigeria, $64.5 \%$ of women were found to be obese, most of whom visited "the fattening room" where women are treated to become fat after delivery [1]. This study has demonstrated a $29.4 \%$ prevalence of overweight and $19.5 \%$ prevalence of obesity (with a peak age prevalence of 45 54 years) among dwellers in one of the communities in Enugu metropolis. It also demonstrated an increasing mean of systolic and diastolic blood pressures with increasing BMI. Significant correlates of obesity in the index study were female gender, systolic and diastolic blood pressures, fasting blood glucose and level of 
physical activity.

The prevalence of overweight (29.4\%) in the index study is higher than $16.1 \%$ reported in Maiduguri, and 22.9\% in the south-south zone of the country [1] [2] [3]. Studies conducted in selected groups such as civil servants, office workers and urban dwellers have shown higher prevalences [3] [20] [31]. The prevalence of overweight reported in other African countries also varied widely between and within countries [24] [23] [24] [26].

The reported prevalence of obesity in the index study is within the range previously reported not only in Nigeria but also from another part of SSA [1]-[6] [20] [21] [22]. Studies from Nigeria showed a range of $4.6 \%$ (in Maiduguiri) to 62.6\% in Akwa Ibom [2] [14] depending on the location and the group studied. All studies done among civil servants/office workers in all parts of Nigeria gave high prevalences of obesity [13] [14] [21]. Together with the index report, these previous studies support the increasing burden of overweight and obesity and its attendant consequences in SSA. In the West African sub-region, an overall prevalence of $10 \%$ was reported by Abubakari et al. [10], nevertheless, it differed widely between countries [5] [6] [12] [33] [34]. A major limitation in comparing these studies is the use of different criteria in the assessment of overweight/obesity and study location (rural and urban vs rural only or urban only) as well as age group surveyed.

The mean BMI $\left(25 \mathrm{~kg} / \mathrm{m}^{2}\right)$ is similar to reports by Nwoka et al. [31] in Sokoto but lower than $30 \mathrm{~kg} / \mathrm{m}^{2}$ and $35.2 \mathrm{~kg} / \mathrm{m}^{2}$ reported by Adienobo et al. [1] among the Kalabaris in Port Harcourt and Ogunjimi et al. [14] in Akwa Ibom among nurses. Like many studies emanating from urban areas, the prevalence of overweight and obesity may be considered to be high in the index study. Several explanations have been posited for the urban rural dichotomy in the prevalence of overweight/obesity. Urbanization has been associated with the increased availability of energy-rich foods that have been shown to particularly influence the quality of diets and nutritional well-being [2] [5] [6] [13] [18] [31] [35] [36] [37]. This has always involved a shift from traditional diets and lifestyle to foods rich in fat and refined sugars as well as adopting sedentary lifestyles. Whereas in rural areas everyday activity may involve a lot of manual labor and walking long distances, urban dwellers are more likely to take modern means of transportation, work in offices/factories or become traders. The distribution and pattern of different classes of obesity show that most subjects had class I obesity. This is similar to reports by Amira et al. [15].

Some studies commented on the prevalence of underweight in their cohorts. We reported a prevalence of $4 \%$ which is close to $3.1 \%$ reported by Amira et al. [15] but much higher than $1 \%, 0.7 \%$ and $1.7 \%$ reported by Adienbo et al. [1], Iwuala et al. [38] and Desalu et al. [20]. In a study from Northeastern Nigeria, the prevalence of underweight was as high as $29.1 \%$ [2].

As in most studies, women in this study weighed more than men and female gender was strongly associated with obesity. High prevalence of obesity in women is almost universal in African countries [6] [9] [10] [39] [40] [41]. Fe- 
male predominance has been linked to marital status, multiple pregnancies and hormonal changes especially following menopause and socio-cultural practices, perceptions and norms [1] [5] [39] [40] [42]. Until recently, in south-east Nigeria where this study was conducted women and children are expected to be "well nourished" and be "presentable" in order not to put the family to shame. A positive association between obesity and food insecurity has been described in women [43] [44] suggesting that women of all socioeconomic class may be at risk of developing obesity in SSA.

The age distribution of obesity showed a peak age range of 45 - 54 years similar to the findings by Amira et al. [15] in Lagos. Although in the present study the peak age range was similar in males and females, it was different in other studies [3] [5] [6]. A number of studies in SSA have reported a positive association between age and obesity [5] [6] [38] [45], unlike the index study. The peak age of obesity in this study ( 45 - 54 years) gradually declined to $16.9 \%$ after 65 years. Other studies have also identified this trend [46] [47]. This age distribution of overweight and obesity is a factor that should be considered by policymakers and public health educators in developing educational interventions in the country.

This study noted a significant increase in mean SBP, DBP and FBG with a increase in BMI with DBP as a significant predictor of obesity among the three variables. The relationship between obesity, hypertension and diabetes/hyperinsulinemia is well described among Nigerians in studies on metabolic syndrome [5] [6] [7] [8] [12]. Generally, the risk of hypertension increases with BMI. This is thought to be caused by increased fatty tissue which elevates vascular resistance which in turn increases afterload and sympathetic tone leading to the activation of renin angiotensin system hence a vicious loop is formed. Leptin 5 (and other neuropeptides), hyperinsulinemia also provide possible links between obesity and high blood pressure [8]. This relationship may also explain the positive correlation between fasting blood glucose and obesity. A significant increase in the incidence of hypertension among obese participants, without a history of hypertension, has been recorded in a cohort of obese individuals [48] [49] [50].

As expected, obesity was more prevalent in people with sedentary lifestyles $25.3 \%$.

Obesity increased with decreasing levels of physical activity in the present study. This agrees with previous studies [51] [52] [53]. Several factors such as urbanization, occupation and unhealthy diet lead to obesity by reducing the level of physical activity. Iwuala et al. [38] reported that $79.2 \%$ of healthcare workers who were described as living sedentary lifestyles were twice more likely to be overweight compared to those who were physically active.

In this study, we found a weak correlation between obesity and tobacco use and no correlation with alcohol intake. The association between alcohol consumption, smoking, and obesity is not consistent [5] [6] [53]. There is some evidence that such associations may depend on gender [6] [54]. Tobacco was used 
in one form or the other in $22.1 \%$ of the subjects; higher in males $38.2 \%$ than in females $14.7 \%$. This high rate of tobacco use was because we included the use of all forms of tobacco in the analysis. The current rate of tobacco use is likely to be more representative than rates of cigarette smoking reported in other studies. Previous studies on rates of cigarette smoking range between (13.1\%) and $32.8 \%$ [3] [18] [20]. Similar to some of these studies, tobacco was used commonly among males. Obesity has been reported to be higher among smokers [54]. Tobacco has an additive effect to that of overweight and obesity as major risk factors for cardiovascular disease. In addition to the high rate of hypertension found in the index study, many of the subjects are in danger of severe cardiovascular events. The weak correlation noted in the index study may be explained by the inclusion of all forms of tobacco use.

The main limitation of the present study is the number and people and locations studied within Enugu metropolis hence may not be representative of the entire population of Enugu urban or state. Further studies involving urban and rural areas of the State are required to obtain an overall prevalence of obesity in the state. The cross-sectional design of this study does not allow longitudinal evaluation of body mass over time especially with relation to physical activity. This is important because of the growing awareness of physical activity and cardiovascular disease prevention in Nigeria. Nevertheless, this study provides an estimate of overweight and obesity in Enugu which may be used as a reference point for other studies from the city and region.

\section{Recommendations}

Public health education programs using different media should emphasise the rising problem of obesity and health risks related to it. The problems associated with obesity should be included in the basic school curriculum early enough in our institutions. The increasing awareness of physical fitness should be encouraged especially in schools and places of work.

\section{Acknowledgments}

The authors wish to acknowledge the help and support of the inhabitants of the two settlements as well as their religious leaders.

\section{Funding}

The project described was supported by the Medical Education Partnership Initiative in Nigeria (MEPIN) project funded by Fogarty International Center, the Office of AIDS Research, and the National Human Genome Research Institute of the National Institute of Health, the Health Resources and Services Administration (HRSA) and the Office of the U.S. Global AIDS Coordinator under Award Number R24TW008878. The content is solely the responsibility of the authors and does not necessarily represent the official views of the funding organizations. 


\section{Conflicts of Interest}

The authors declare no conflicts of interest regarding the publication of this paper.

\section{References}

[1] Adienbo, O.M., Hart, V.O. and Oyeyemi, W.A. (2012) High Prevalence of Obesity among Indigenous Residents of a Nigerian Ethnic Group: The Kalabaris in the Niger Delta Region of South-South Nigeria. Greener Journal of Medical Science, 2, 152-156. https://doi.org/10.15580/GJMS.2012.5.110512215

[2] Aliyu, S.U., Chiroma, A.C., Jajere, A.M. and Gujba, F.U. (2015) Prevalence of Physical Inactivity, Hypertension, Obesity and Tobacco Smoking: A Case of NCDs Prevention among Adults in Maiduguri, Nigeria. American Journal of Medical Sciences and Medicine, 3, 39-47.

[3] Chukwuonye, I.I., Chuku, A., John, C., Ohagwu, K.A., Imoh, E.R., Isa, S.E., Ogah, O.S. and Oviasu, E. (2013) Prevalence of Overweight and Obesity in Adult Nigerians-A Systematic Review. Diabetes, Metabolic Syndrome and Obesity. Targets and Therapy, 6, 43-47. https://doi.org/10.2147/DMSO.S38626

[4] Yusuf, S., Reddy, S., Ounpuu, S. and Anand, S. (2001) Global Burden of Cardiovascular Diseases: Part I: General Considerations, the Epidemiologic Transition, Risk Factors, and Impact of Urbanization. Circulation, 104, 2746-2753. https://doi.org/10.1161/hc4601.099487

[5] Adeboye, B., Bermano, G. and Rolland, C. (2012) Obesity and Its Health Impact in Africa: A Systematic Review. Cardiovascular Journal of Africa, 23, 512-521. https://doi.org/10.5830/CVJA-2012-040

[6] McLarty, D.G., Pollitt, C. and Swai, A.B. (1990) Diabetes in Africa. Diabetic Medicine, 7, 670-684. https://doi.org/10.1111/j.1464-5491.1990.tb01470.x

[7] Okafor, C.I. (2012) The Metabolic Syndrome in Africa: Current Trends. Indian Journal of Endocrinology and Metabolism, 16, 56-66. https://doi.org/10.4103/2230-8210.91191

[8] Hanlon, P., Byers, M., Walker, B.R. and Macdonald, H.M. (2010) Environmental and Nutritional Factors in Disease. In: Davidson's Principle and Practice of Medicine, 21st Edition, Churchill Livingstone Elsevier, London, 116-121.

[9] World Health Organization (2015) Obesity and Overweight. Factsheet. https://www.who.int/topics/obesity/en/

[10] Abubakari, A.R., Lauder, W., Agyemang, C., Jones, M., Kirk, A. and Bhopal, R.S. (2008) Prevalence and Time Trends in Obesity among Adult West African Populations: A Meta-Analysis. Obesity Reviews, 9, 297-311. https://doi.org/10.1111/j.1467-789X.2007.00462.x

[11] Akinkugbe, O.O. (1997) Final Report of National Survey on Non-Communicable Diseases in Nigeria. Federal Ministry of Health and Social Services.

[12] Abubakari, A.R. and Bhopal, R.S. (2008) Systematic Review on the Prevalence of Diabetes, Overweight/Obesity and Physical Inactivity in Ghanaians and Nigerians. Public Health, 122, 173-182. https://doi.org/10.1016/j.puhe.2007.06.012

[13] Aladeniyi, I., Adeniyi, O.V., Fawole, O., Adeolu, M., Ter Goon, D., Idowu, A. and Owolab, F.O. (2017) Pattern and Correlates of Obesity among Public Service Workers in Ondo State, Nigeria: A Cross-Sectional Study. South African Family Practice, 59, 195-200. https://doi.org/10.1080/20786190.2017.1333784

[14] Ogunjimi, L.O., Ikorok, M.M., Yusuf, N. and Olayinka, O. (2010) Prevalence of Obesity among Nigeria Nurses: The Akwa Ibom State Experience. International 
NGO Journal, 5, 45-49.

[15] Amira, C.O., Sokunbi, D.O.B., Dolapo, D. and Sokunbi, A. (2011) Prevalence of Obesity, Overweight and Proteinuria in an Urban Community in South West Nigeria. Nigerian Medical Journal, 52, 110-113.

[16] Adegoke, O.A., Adedoyin, R.A., Balogun, M.O., Adebayo, R.A., Bisiriyu, L.A. and Salawu, A.A. (2010) Prevalence of Metabolic Syndrome in a Rural Community in Nigeria. Metabolic Syndrome and Related Disorders, 8, 59-62. https://doi.org/10.1089/met.2009.0037

[17] Amole, I.O., Ola Olorun, A.D., Odeigah, L.O. and Adesina, S.A. (2011) The Prevalence of Abdominal Obesity and Hypertension amongst Adults in Ogbomoso, Nigeria. African Journal of Primary Health Care \& Family Medicine, 3, a188. https://doi.org/10.4102/phcfm.v4i1.188

[18] Oyeyemi, A.L., Adegoke, B.O., Oyeyemi, A.Y., Deforche, B., De Bourdeaudhuij, I. and Sallis, J.F. (2012) Environmental Factors Associated with Overweight among Adults in Nigeria. International Journal of Behavioral Nutrition and Physical Activity, 9, 32. https://doi.org/10.1186/1479-5868-9-32

[19] Adedoyin, R.A., Mbada, C.E., Balogun, M.O., Adebayo, R.A., Martins, T. and Ismail S. (2009) Obesity Prevalence in Adult Residents of Ile-Ife, Nigeria. Nigerian Quarterly Journal of Hospital Medicine, 19, 100-105. https://doi.org/10.4314/nqjhm.v19i1.50211

[20] Desalu, O.O., Salami, A.K., Oluboyo, P.O. and Olarinoye, J.K. (2008) Prevalence and Socio-Demographic Determinants of Obesity among Adults in an Urban Nigerian Population. Sahel Medical Journal, 11, 61-64. https://doi.org/10.4314/smj2.v11i2.12970

[21] Awosan, K.J., Ibrahim, M.T.O., Arisegi, S.A., Ejimadu, S.P., Erhiano, E.E. and Aderahman, A.T. (2013) Prevalence of Metabolic Syndrome and Its Components among Civil Servants in a Metropolitan City in Northern Nigeria. Global Advanced Research Journal of Medicine and Medical Sciences, 2, 238-246.

[22] Bakari, A.G., Onyemelukwe, G.C., Sani, B.G., Aliyu, I.S., Hassan, S.S. and Aliyu, T.M. (2007) Obesity, Overweight and Underweight in Suburban Northern Nigeria. International Journal of Diabetes \& Metabolism, 15, 68-69.

[23] Sagna, Y., Yanogo, D.R., Tiéno, H., Guira, O., Bagbila, A.P., Bognounou, R., Zoungrana, L., Ouedragogo, D.-D. and Drabo, Y.P. (2014) Obesity and Metabolic Syndrome in a Burkina Faso Urban Area: Prevalence, Associated Factors and Comorbidities. Journal of Nutritional Disorders and Therapy, 4, 141.

https://doi.org/10.4172/2161-0509-4.1000141

[24] Biritwum, R., Gyapong, J. and Mensah, G. (2005) The Epidemiology of Obesity in Ghana. Ghana Medical Journal, 39, 82-85.

[25] Djrolo, F., Gbary, A. and Akoha, S.E.R. (2012) Prévalence de l'obésité et de la surcharge pondérale dans population adulte à Cotonou, Bénin. Annales d Endocrinologie, 373, 424. https://doi.org/10.1016/j.ando.2012.07.732

[26] WHO (2005) WHO STEP Wise Approach to Chronic Disease Risk Factor Surveillance (STEPS). WHO, Geneva.

[27] World Health Organization (2000) Obesity: Preventing and Managing the Global Epidemic.

[28] O’Brien, E., Asmar, R., Beilin, L., Imai, Y., Mancia, G., Mengden, T., Meyers, M., Palatini, P., Parati, G., Pickering, T., Redon, J., Staessen, J., Stergiou, G. and Verdecchia, P. (2005) Practice Guidelines of the European Society of Hypertension for Clinic, Ambulatory and Self Blood Pressure Measurement. Journal of Hypertension, 
23, 697-701. https://doi.org/10.1097/01.hjh.0000163132.84890.c4

[29] Powers, A.C. (2005) Diabetes Mellitus. In: Kasper, D.L., Fauci, A.S., Longo, D.L., Braunwald, E., Hauser, S.L. and Jameson, J.L., Eds., Harrison's Principles of Internal Medicine, 16th Edition, McGraw-Hill, New York, 2152-2180.

[30] U.S. Department of Health and Human Services (2008) Physical Activity Guidelines for Americans. http://www.health.gov/paguidelines

[31] Nkwoka, I.J., Egua, M.O., Abdullahi, M., Sabi'u, A. and Mohammed, A.I. (2014) Overweight and Obesity among Staff of Usmanu Danfodiyo University, Sokoto, Nigeria. Educational Research, 5, 290-295.

[32] Yamane, T. (1967) Statistics: An Introductory Analysis. 2nd Edition, Harper and Row, New York.

[33] Ziraba, A.K., Fotso, J.C. and Ochako, R. (2009) Overweight and Obesity in Urban Africa: A Problem of the Rich or the Poor? BMC Public Health, 9, 465. https://doi.org/10.1186/1471-2458-9-465

[34] Tulip, O.L., Obidi, O.F., Oyesile, T.C. and Einstein, G.P. (2018) The Prevalence of Adult Obesity in Africa: A Meta-Analysis. Gene Reports, 11, 124-126. https://doi.org/10.1016/j.genrep.2018.03.006

[35] Epacka, E.M., Mandengue, S.H. and Ahmadou, G. (2011) Dépistage des maladies cardiovasculaires et des facteurs de risqué dans une cohorte de 270 Camerounais? Effets des activités physiques et sportives. Médecine Mal Métaboliques, 5, 655-658. https://doi.org/10.1016/S1957-2557(11)70342-X

[36] Adejumo, E.N., Ogundahunsi, O.A., Adejumo, O.A., Sotunsa, J. and Jagun, O. (2027) Prevalence of Metabolic Syndrome in a Rural and Urban Community in South-West Nigeria Using Three Different Definitions. International Journal of Tropical Disease \& Health, 24, 1-9. https://doi.org/10.9734/IJTDH/2017/33993

[37] BeLue, R., Okoror, T.A., Iwelunmor, J., Taylor, K.D., Degboe, A.N., Agyemang, C. and Ogedegbe, G. (2009) An Overview of Cardiovascular Risk Factor Burden in Sub-Saharan African Countries: A Socio-Cultural Perspective. Globalization and Health, 5, 10. https://doi.org/10.1186/1744-8603-5-10

[38] Iwuala, S.O., Sekoni, A.O., Olamoyegun, M.A., Akanbi, M.A., Sabir, A.A. and Ayankogbe, O.O. (2015) Self-Reported Physical Activity among Health Care Professionals in South-West Nigeria. Nigerian Journal of Clinical Practice, 18, 790-795. https://doi.org/10.4103/1119-3077.163275

[39] Pereko, K.K., Setorglo, J., Owusu, W.B. and Tiweh, J.M. (2013) Overnutrition and Associated Factors among Adults Aged 20 Years and above in Fishing Communities in the Urban Cape Coast Metropolis, Ghana. Public Health Nutrition, 16, 591-595. https://doi.org/10.1017/S1368980012002698

[40] Prentice, A.M. (2006) The Emerging Epidemic of Obesity in Developing Countries. International Journal of Epidemiology, 35, 93-99. https://doi.org/10.1093/ije/dyi272

[41] Njelekela, M.A., Mpembeni, R, Muhihi, A., Mligiliche, N.L., Spiegelman, D., Hertzmark, E., Liu, E., Finkelstein, J.L., Fawzi, W.F., Willett, W.C. and Mtabaji, J. (2009) Gender-Related Differences in the Prevalence of Cardiovascular Disease Risk Factors and Their Correlates in Urban Tanzania. BMC Cardiovascular Disorders, 9 , 30. https://doi.org/10.1186/1471-2261-9-30

[42] Amoah, A.G. (2003) Sociodemographic Variations in Obesity among Ghanaian Adults. Public Health Nutrition, 6, 751-757. https://doi.org/10.1079/PHN2003506

[43] Townsend, M.S., Peerson, J., Love, B., Achterberg, C. and Murphy, S.P. (2001) Food Insecurity Is Positively Related to Overweight in Women. The Journal Nutrition, 
131, 1738-1745. https://doi.org/10.1093/jn/131.6.1738

[44] Chaput, J.-P., Gilbert, J.A. and Tremblay, A. (2007) Relationship between Food Insecurity and Body Composition in Ugandans Living in Urban Kampala. Journal of the Academy of Nutrition and Dietetics, 107, 1978-1982.

https://doi.org/10.1016/j.jada.2007.08.005

[45] Iloh, G., Amadi, A.N., Nwankwo, B.O., et al. (2011) Obesity in Adult Nigerians: A Study of Its Pattern and Common Primary Co-Morbidities in a Rural Mission General Hospital in Imo State, South-Eastern Nigeria. Nigerian Journal of Clinical Practice, 14, 212-218. https://doi.org/10.4103/1119-3077.84019

[46] Flegal, K.M., Carroll, M.D., Ogden, C.L. and Johnson, C.L. (2002) Prevalence and Trends in Obesity among US Adults, 1999-2000. Journal of American Medical Association, 288, 1723-1727. https://doi.org/10.1001/jama.288.14.1723

[47] Dua, S., Bhuker, M., Sharma, P., Dhall, M. and Kapoor, S. (2014) Body Mass Index Relates to Blood Pressure among Adults. North American Journal of Medical Sciences, 6, 89-95. https://doi.org/10.4103/1947-2714.127751

[48] Vuvor, F. (2017) Correlation of Body Mass Index and Blood Pressure of Adults of 30-50 Years of Age in Ghana. Journal of Health Research and Reviews, 4, 115-121. https://doi.org/10.4103/jhrr.jhrr_93_16

[49] Tesfaye, F., Nawi, N.G., Van Minh, H., Byass, P., Berhane, Y., Bonita, R. and Wall, S. (2007) Association between Body Mass Index and Blood Pressure across Three Populations in Africa and Asia. Journal of Human Hypertension, 21, 28-37. https://doi.org/10.1038/sj.jhh.1002104

[50] Yanogo, R.D., Sagna, Y., Tieno, H., Guira, O. and Drabo, Y.J. (2014) Prevalence of Diabetes and Cardiovascular Risk Factors in Ouagadougou (Burkina-Faso). Open Access Library Journal, 1, e595. https://doi.org/10.4236/oalib.1100595

[51] Ibhazehiebo, K., Dimkpa, U. and Iyawe, V. (2007) Hypertension, and Blood Pressure Response to Graded Exercise in Young Obese and Non-Athletic Nigerian University Students. Nigerian Journal of Physiological Sciences, 22, 37-42. https://doi.org/10.4314/njps.v22i1-2.54886

[52] Shayo, G.A. and Mugusi, F.M. (2011) Prevalence of Obesity and Associated Risk Factors among Adults in Kinondoni Municipal District, Dar es Salaam Tanzania. BMC Public Health, 11, 365. https://doi.org/10.1186/1471-2458-11-365

[53] Msyamboza, P.K., Kathyola, D. and Dzowela, T. (2013) Anthropometric Measurements and Prevalence of Underweight, Overweight and Obesity in Adult Malawians: Nationwide Population Based NCD STEPS Survey. Pan African Medical Journal, 15, 108. https://doi.org/10.11604/pamj.2013.15.108.2622

[54] Agbeko, M.P., Kumi-Kyereme, A., Druye, A.A., et al. (2013) Predictors of Overweight and Obesity among Women in Ghana. The Open Obesity Journal, 5, 72-81. https://doi.org/10.2174/1876823701305010072 